\title{
O NOSSO PROGRAMA
}

Já em 1937, quando ainda lecionava na Faculdade de Filosofia, Ciências e Letras da Universidade de São Paulo, o ilustre Prof. Fernand Paul Braudel - com quem tivemos a honra de trabalhar na qualidade de assistente - pensávamos em fundar uma Revista destinada à divulgação de trabalhos históricos, não só de professôres e assistentes, mas também de licenciados e alunos.

Motivos vários, entretanto, impediram a concretização dessa idéia que, só agora, vencidos em grande parte os óbices antigos, pode ser levada a efeito, embora com as naturais ressalvas de ordem técnica e científica.

Aparece assim a nossa Revista. O seu objetivo precípuo é oferecer aos estudiosos uma oportunidade de divulgação sistemática, e mais ou menos ampla, dos trabalhos e das pesquisas que o amor ao estudo e a dedicação ao magistério universitário propiciam e orientam.

Supomos que tal divulgação, conquanto não possa corresponder inteiramente aos anseios dos jovens pesquisadores, conseguirá encorajá-los e estimulá-los, a ponto de os levar à intensificação dos seus labores e ao aprimoramento de sua cultura histórica.

Mas a Revista quer ter também outra finalidade; quer ser o traço de união entre a Faculdade e os professôres de História do ensino normal e secundário. Para isso pretende fornecer-lhes bibliografias sempre atualizadas, interpretações novas de fatos históricos em geral, resenhas críticas de obras recentes, comentários desapaixonados à margem de assuntos contravertidos e documentos antigos devidamente estudados. Tudo, enfim, quanto possa obviar, em parte, as naturais deficiências das bibliotecas existentes no interior do Estado.

Escusado será dizer que não pretendemos, de forma alguma, competir com as publicações especializadas já existen- 
tes no país, e principalmente com as que se dedicam aos assuntos da História Pátria; pretendemos, isso sim, merecer um modesto lugar entre elas, dando publicidade a trabalhos que provàvelmente não poderiam ser acolhidos em suas páginas, à vista das exigências muito razoáveis da especialização, às quais devem subordinar-se.

Contamos desde já com o apôio valioso dos Departamentos de História e de Etnografia, de nossa Faculdade, com os Professôres de História Econômica da Faculdade de Ciências Econômicas da Universidade de São Paulo e da Escola de Sociologia e Política, e com a cooperação de conhecidos historiadores do Rio de Janeiro, dentre os quais podemos destacar: Eremildo Luiz Vianna, Jayme Coelho, Delgado de Carvalho, Hélio Vianna, Sílvio Júlio e Artur César Ferreira Reis.

Compreendendo a História como "Ciência do Homem", segundo o conceito de Lucien Febvre, estamos certos de que não nos faltará também o apôio de quantos, no âmbito universitário ou fora dêle, cuidem de assuntos de fundo histórico. A largueza de nosso campo de ação permitirá, sem dúvida, o acolhimento de trabalhos sôbre quaisquer dos setores da História: econômico, social, político, religioso, literário, filosófico e científico.

Para sintetizar tão largo programa, precisávamos, evidentemente, para a nossa Revista, de um designativo capaz de afastar desde logo qualquer preocupação restrictiva. E foi graças a gentileza do nosso eminente colega, Prof. Fidelino de Figueiredo, que pudemos satisfazer inteiramente aos nossos desejos, adotando a denominação: Revista be História. Consentiu o ilustre Professor que retomássemos o prestigioso título de uma sua antiga publicação (1912-1928), e nós, congratulando-nos com isso, tomá-la-emos como modêlo da nossa, pondo desde já ao serviço de todos os Homens de Boa Vontade, a nova Revista de História.

E. SIMÕES DE PAULA 